Nadwa | Jurnal Pendidikan Islam

Vol. 11, Nomor 1, Tahun 2017

\title{
Signifikansi Brain Based Learning Pendidikan Anak Usia Dini
}

\author{
Jazariyah \\ UIN Sunan Kalijaga Yogyakarta \\ jaza.prudent@gmail
}

\begin{abstract}
This study based on the reality of learning in the early childhood level and the system has not noticed the potential of the brain learners. The potential and the working system of the brain is very important in early childhood. This paper aims to reveal the importance of brain-based learning in Early Childhood Education (ECD). The problem in this study are what the nature of early childhood education and how to use the potential and work system of the brain in early childhood learning. This study used library research. From the discussion showed that the brain-based learning was important for use in teaching and learning of young children. One of aplication, brainbased learning use quantum learning by optimizing learning with active learning strategies so that potential students can be optimized. This research had contribution to brain based learning
\end{abstract}

Keywords: early childhood education; brain based learning; quantum learning

\begin{abstract}
Abstrak
Kajian ini dilatarbelakangi oleh realitas masih adanya pembelajaran di jenjang PAUD yang belum memperhatikan potensi dan system kerja otak peserta didik. Padahal potensi dan system kerja otak sangat penting dalam pembalajaran di PAUD. Tulisan ini bertujuan untuk mengungkapkan pentingnya brain based learning pada Pendidikan Anak Usia Dini (PAUD). Rumusan masalah pada kajian ini adalah seperti apa hakikat Pendidikan Anak Usia Dini dan bagaimana penggunaan potensi dan system kerja otak dalam pembelajaran anak usia dini. Penelitian ini menggunakan metode library research Dari hasil pembahasan menunjukkan bahwa brain based learning penting untuk digunakan dalam proses belajar mengajar anak usia dini. Salah satu pelaksanaan pembelajaran berbasis otak ini dapat menggunakan pembelajaran quantum dengan mengoptimalkan pembelajaran dengan strategi pembelajaran aktif sehingga potensi anak didik dapat dioptimalkan. Penelitian ini memiliki kontribusi pada pembelajaran berbasis otak.
\end{abstract}

Kata Kunci : PAUD, brain based learning, quantum learning 


\section{Pendahuluan}

Persoalan paling mendasar dalam penyelenggaran pendidikan di jenjang Anak Usia Dini (AUD) adalah terkait dengan proses pembelajarannya. Hal ini dikarenakan pendidikan pada jenjang ini melibatkan peserta didik pemula. Di mana peserta didik masih sangat lemah, belum mandiri, belum matang yang membutuhkan bimbingan, arahan, perlindungan ektra. Sehingga konsep pembelajaran pada jenjang ini bersifat developmental yakni menitikberatkan pada pertumbuhan dan perkembangan fisik (koordinasi motorik halus dan kasar), kecerdasan (daya pikir, daya cipta, kecerdasan emosi, kecerdasan spiritual), sosial emosional (sikap dan perilaku), bahasa (komunikasi), sesuai dengan keunikan dan tahap-tahap perkembangan yang dilalui oleh anak usia dini.

Di samping itu persoalan lain dalam pembelajaran di jenjang AUD adalah tuntutan penanganan peserta didik secara individual. Hal ini dikarenakan adanya realitas bahwa setiap peserta didik memiliki keunikan masing-masing. Setiap anak terlahir dengan keunikan tersendiri yang tidak dipunyai oleh anak lain. Realitas ini menuntut penanganan peserta didik yang berbeda-beda. Dengan demikian tuntutan terhadap penanganan terhadap keunikan individu ini menjadi bagian penting yang mesti diperhatikan dalam pendidikan di PAUD.

Namun demikian dalam kenyataanya belum semua sivitas akademis PAUD melaksanakan pembelajaran yang memperhatikan keunikan peserta didik. Realitas menunjukkan masing sering orang tua ataupun pendidik melaksanakan proses pembelajaran untuk anak usia dini tanpa mempertimbangkan keunikan yang ada pada diri setiap anak. Mereka cenderung menyamaratakan kemampuan setiap anak. Selanjutnya mereka memberikan treatment yang sama kepada setiap peserta didik. Realitas ini menjadi persoalan mendasar yang mesti diperhatiakn dalam pembelajaran di PAUD.

Semestinya pembelajaran AUD yang mengakomodir perbedaan karakteristik dan kemampuan peserta didik harus mulai dikembangkan para pengelola PAUD. Sebab mengakomodir perbedaan peserta didik menjadi dasar utama pembelajaran AUD yang berkualitas. Pembelajaran berkualatas 
adalah proses pembelajaran yang mengedepankan pembentukan kecerdasan anak berdasarkan potensi-potensi yang dimiliki oleh anak itu sendiri. Dengan demikian untuk menciptakan pembelajaran berkualitas tidak mungkin tanpa mengakomodir perbedaan peserta didik dalam pengelolaan dan pembelajaran PAUD.

Salah satu pendekatan pembelajaran yang dapat digunakan dalam memperhatikan keunikan individu adalah dengan brain based learning. Brain based learning merupakan salah satu bentuk pembelajaran yang menekankan pada upaya stimulus potensi dan kerja otak peserta didik. Dengan kata lain bentuk pembelajaran ini berangkat dari pandangan bahwa setiap individu memiliki kecerdasan otak yang berbeda-beda. Perbedaan kecerdasan ini kemudian menuntut penaganan yang berbeda-beda pula dalam mengmbangkannya. Dengan demikian brain based learning merupakan salah satu bentuk pembelajaran yang penting untuk mencapai perkembangan otak anak secara optimal.

Berdasarkan latarbelakang di atas maka penulis membuat artikel dengan judul Signifikansi Brain Based Learning Pendidikan Anak Usia Dini. Adapun tulisan ini akan terbagi menjadi sub-bab sebagai berikut: hakikat pendidikan anak usia dini, potensi otak dalam pembelajaran anak usia dini, brain management, brain based learning dalam pendidikan anak usia dini dan quantum learning

\section{Hakikat Pendidikan Anak Usia Dini}

Program Pendidikan Anak Usia Dini (PAUD) tidak dimaksudkan untuk mencuri start apa-apa yang seharusnya diperoleh pada jenjang pendidikan dasar, tetapi untuk memberikan fasilitasi pendidikan yang sesuai bagi anak. Sehingga anak lebih siap dan matang baik secara fisik, mental, sosialataupun emosional dalam rangka memasuki pendidikan lebih lanjut. ${ }^{1}$ Pendidikan anak usia dini sebagai dasar yang akan menentukan masa depan anak-anak bangsa. Apabila pendidik

${ }^{1}$ Direktorat Pendidikan Anak Usia Dini, Pedoman Penerapan Pendekatan "Beyond Centers And Circle Time (BCCT)" (Pendekatan Sentra Dan Lingkaran) Dalam Pendidikan Anak Usia Dini (Jakarta: Departemen Pendidikan Nasional, 2006). 
dan orang tua melakukan kesalahan dalam menentukan dan meletakkan dasar-dasar pengetahuan pada anak usia dini, maka akan sangat sulit mengembalikannya ke arah yang diinginkan setelah anak menjadi dewasa.

Dalam Undang-Undang Nomor 20 Tahun 2003 tentang Sistem Pendidikan Nasional Pasal 1 angka 14 menyatakan bahwa Pendidikan Anak Usia Dini (PAUD) adalah suatu upaya pembinaan yang ditujukan kepada anak sejak lahir sampai dengan usia enam tahun yang dilakukan melalui pemberian rangsangan pendidikan untuk membantu pertumbuhan dan perkembangan jasmani dan rohani, agar anak memiliki kesiapan dalam memasuki pendidikan lebih lanjut. Berdasarkan pengertian yang tercantum dalam undang-undang tersebut ada beberapa hal yang perlu dicatat terkait PAUD. Pertama, PAUD yang diselenggarakan di negara kita ini diperuntukan untuk anak usia 0-6 tahun; kedua, PAUD merupakan wadah untuk pemberian rangsangan atau stimulasi pertumbuhan dan perkembangan anak usia dini; ketiga; Penyelenggaraan PAUD ditujukan agar anak-anak lebih siap dalam menghadapi jenjang pendidikan lebih lanjut atau tahapan selanjutnya.

Pendidikan Anak Usia Dini (PAUD) merupakan bagian dari pencapaian tujuan pendidikan nasional, sebagaimana yang telah diatur dalam Undang-Undang No. 20 tahun 2003 tentang Sistem Pendidikan Nasional. ${ }^{2}$ Landasan-landasan yuridis lain yang mengatur PAUD antara lain UU No 23 Tahun 2003 tentang Perlindungan Anak, Permendikbud No. 146 tahun 2014 tentang Kurikulum 2013 PAUD, Permendikbud No. 137 Tahun 2014 tentang Standar Nasional PAUD. Selain itu ada juga Peraturan Presiden RI No. 60 Tahun 2013, tentang penyelenggaraan PAUD Holistik Integratif (HI)

Banyaknya kebijakan kebijakan yang dikeluarkan oleh pemerintah menunjukkan pentingnya kedudukan pendidikan anak usia dini. Pondasi yang kuat dibangun melalui PAUD, anak-anak sebagai generasi penerus bangsa mendapatkan bekal untuk masa depannya baik dalam hal pembentukan karakter maupun kognitif berawal dari pendidikan yang ditanamkan sejak

\footnotetext{
${ }^{2}$ Noor Rochmad Ali, Jazariyah, and Rina Roudlatul Jannah, Perkembangan Dan Permainan Edukatif Anak Usia Dini (Yogyakarta: Editie Pustaka, 2016).
} 
dini. Pendidikan Anak Usia Dini dapat dilakukan baik melalui jalur formal maupun non formal dan informal.

PAUD memegang peranan penting dan menentukan bagi sejarah perkembangan anak selanjutnya karena merupakan fondasi bagi dasar kepribadian anak. Menurut Al Ghazali : Anak sebagai amanah Allah, hatinya yang masih suci, siap menerima segala bentuk ajaran dan penanaman nilai sebagaimana kertas kosong yang masih putih. ${ }^{3}$ Untuk itu bagaimana pembelajaran pada Pendidikan Anak Usia Dini dapat terserap dengan baik dan tepat untuk setiap anak haruslah dipikirkan. Orang tua ataupun pendidik perlu mengetahui tahapan perkembangan anak serta perkembangan otak dan potensi otak anak usia dini. Sehingga segala upaya pembinaan yang dilakukan dapat membuahkan hasil yang sesuai dengan harapan.

\section{Potensi Otak dalam Pembelajaran Anak Usia Dini}

Otak sebenarnya disusun oleh 100 miliar sel-sel otak (neuron) dan 100 triliun sel pendukung (sel glia). Jumlah yang sangat spektakuler ini mungkin melebih galaksi yang ada di alam semesta. Hasil interaksinya membentuk pikiran, pengalaman dan pribadi manusia. Jika seseorang mendapatkan tambahan informasi baru maka sel-sel saraf ini secepat mungkin akan membentuk koneksi satu dengan yang lainnya untuk menyimpan atau memperkuat informasi tersebut. ${ }^{4}$

Ada bagian otak yang disebut amygdala yang tumbuh mencapai puncaknya pada usia 4 tahun. Amygdala ini berkaitan dengan penyimpanan memori emosi/rasa. Karena itu potensi otak anak usia dini akan tercapai optimal apabila rangsangan yang diberikan adalah berupa rangsangan yang diberikan dengan nuansa emosi yang baik seperti kegiatan bermain. Pengalamanpengalaman di usia tersebut akan terpatri dan kuat.

Otak merupakan pusat kecedasan. Otak berfungsi untuk berpikir, mengontrol emosi dan aktivitas gerak tubuh. Dengan demikian apabila kita mampu memahami perkembangan otak manusia, maka kita akan mampu memahami perkembangan

${ }^{3}$ Ihsana El Khuluqo, Manajemen PAUD (Pendidikan Anak Usia Dini) Pendidikan Taman Kehidupan ANak (Yogyakarta: Pustaka pelajar, 2015).

${ }^{4}$ Taufiq Pasiak, Manajemen Kecerdasan (Bandung: Mizan Pustaka, 2007). 
manusia. Demikian halnya pada anak usia dini, dengan memahami perkembangan otak anak usia dini, maka dapat memahami cara mengoptimalkan potensi yang ada pada anak usia dini. $^{5}$

Pertumbuhan otak pada usia dini sangat mempengaruhi tumbuh kembang anak. Sesudah lahir, kegiatan otak dipengaruhi dan tergantung pada kegiatan sel syaraf dan cabang-cabangnya dalam membentuk sambungan antar sel syaraf. Melalui persaingan alami, sambungan yang tidak atau jarang digunakan akan mengalami kematian. Pemantapan sambungan terjadi apabila sel syaraf mendapat informasi yang mampu menghasilkan letupan-letupan listrik hingga membentuk sambungan-sambungan sel syaraf baru. Kualitas kemampuan otak dalam menyerap dan mengolah informasi tergantung dari banyaknya neuron yang membentuk unit-unit. ${ }^{6}$

Otak individu mulai berkembang secara gradual pada saat berusia 2 minggu setelah pembuahan, berkembang dari tabung panjang menjadi sekelompok sel berbentuk bulat. Sembilan bulan kemudian bayi lahir dengan otak dan system saraf yang berisi hampir 100 milyar sel saraf. Otak bayi itu sudah berisi hampir semua sel saraf yang akan dimiliki sepanjang kehidupannya. Namun pola penyambungan antar sel-sel itu masih harus dimantapkan karena pada saat lahir dan pada masa bayi keterkaitan antar sel itu masih lemah. Menginjak usia 2 tahun, saling keterkaitan antar sel-sel saraf meningkat drastis seiring dengan perkembangan bagian sel saraf penerima (dendrit). ${ }^{7}$

Pentingnya stimulasi pada perkembangan otak anak usia dini harus menjadi perhatian pendidik dan juga orang tua. Pertumbuhan otak tidak akan sama dengan pertumbuhan fisik, sel saraf otak tidak dapat bertambah lagi jumlahnya setelah lahir. Tapi jumlah hubungan antar sel saraf otak akan terus

${ }^{5}$ Suyanto, S, Konsep Dasar Pendidikan Anak Usia Dini (Jakarta: Departemen Pendidikan Nasional, 2005).

${ }^{6}$ Atiek Nur Chamidah, "Pentingnya Stimulasi Dini Bagi Tumbuh Kembang Otak Anak," n.d.

${ }^{7}$ J.W Santrock, Life-Span Development Perkembangan Masa Hidup, Edisi Kelima (Jakarta: Erlangga, 2002). 
berlangsung. Jumlah hubungan sel saraf ini sangat bergantung pada stimulasi yang diberikan.

Dari penjelasan diatas bahwa pendekatan perkembangan otak sangat dibutuhkan dalam pembelajaran anak usia dini. Agar anak-anak berkembang secara optimal. Adanya pengetahuan mengenai perkembangan otak pada pendidik maupun orang tua akan sangat membantu dalam pendidikan anak usia dini. Sehingga stimulasi-stimulasi yang digunakan tepat dan efektif dalam mengembangkan otak anak usia dini. Sehingga target pembelajaran pada anak usia dini dapat terwujudkan.

\section{Manajemen Otak (Brain Management)}

Penemuan-penemuan neurosains dewasa ini tidak hanya berguna bagi dunia kedokteran melainkan juga berbagai bidang yang lain seperti psikologi, manajemen dan bisnis serta bidang pendidikan. Bidang pendidikan harusnya sangat diuntungkan dengan adanya temuan-temuan baru di bidang neurosains. Di negara-negara barat, neurosains telah menjadi acuan dalam merumuskan kurikulum pendidikan. Saat ini negara Indonesia pun mulai menggunakan temuan bidang neurosains dalam dunia pendidikan.

Secara umum, ada 10 hukum dasar otak yang relevan di pakai dalam bidang pendidikan. Hukum-hukum itu adalah; 1) keunikan (unique), 2) kekhususan (specificic), 3) sinergitas, 4) hemisferik dan dominasi, 5) verba-grafis, 6) imajinasi dan fakta, 7) plastisitas sel saraf, 8) kerja serempak (simultaneous), 9) simbiosis rasio-spiritualitas, dan 10) otak lelaki-otak perempuan. Istilah-istilah yang dipakai dalam kurang merupakan bawaan (innate) otak manusia. Jadi otak, bukan sekedar struktur (bendaorganik), tetapi fungsi dan sifat. Karena itu, otak merupakan titik utama pengembangan manusia dalam bidang pendidikan. Tidak saja untuk belajar mengajar, tetapi juga bagi pendidikan secara keseluruhan. ${ }^{8}$

Otak manusia adalah komputer terhebat di dunia. Otak merupakan organ atau system yang paling kompleks di dunia. Bahkan sampai sekarang pun seluruh misteri yang terjadi di dalam otak manusia belum seluruhnya dapat diungkap. Walau

${ }^{8}$ Pasiak, Manajemen Kecerdasan. 
ukurannya kecil sehingga otak dapat dimasukkan ke dalam tengkorak kita, otak mampu memuat beberapa kali lipat jumlah informasi yang terkandung di seluruh dunia. ${ }^{9}$

Kerja otak sangat menarik untuk dikaji, otak mengatur semua fungsi tubuh kita. Otak mengendalikan perilaku yang dilakukan oleh manusia. Otak memainkan peran yang sangat penting dalam kehidupan manusia. Namun seberapa jauh otak yang kita miliki ini dimanfaatkan secara optimal sehingga memberikan banyak keuntungan bagi manusia. Sudah menjadi pengetahuan bersama bahwa otak kita terdiri dari dua belahan, dan masing-masing belahan memiliki cara kerja sendiri-sendiri; cara kerja yang berbeda. Pada saat kita memikirkan hal-hal terkait dengan kata, angka atau daftar sesungguhnya kita sedang menggunakan otak belahan kiri. Sedangkan otak belahan kanan bekerja saat kita berimajinasi, kegiatan yang melibatkan irama (musik). Ketika seseorang menari mengikuti irama musik, saat itu belahan otak kanan bekerja.

Dalam mengolah informasi, otak terspesialisasi dalam belahan kiri dan kanan. Kedua belahan otak (hemisfer) ini memiliki cara yang berbeda dalam meproses informasi. Umumnya, tiap-tiap orang memiliki spesialisasi, lebih cenderung memakai salah satu belahan. Ini dikenal dengan istilah dominasi otak. Dominasi otak ini memungkinkan seseorang dengan sangat mudah menjadi seorang analis (rasional) yang gampang mengolah data dan fakta melalui partikularisasi (bagian-bagian) atau menjadi seorang yang kreatif (intuitif) yang mengolah informasi secara lebih menyeluruh dan terpadu. Dengan prinsip seperti ini artinya setiap orang memiliki gaya dan cara yang belajar yang unik. Tidak ada otak yang sama, karena itu tidak ada teknik belajarmengajar yang sama pada semua orang. Transfer informasi akan terjadi dengan baik apabila cara pemerolehan informasi dipahami dengan baik. ${ }^{10}$

${ }^{9}$ Sutanto Windura, Definite success with brain management: panduan manajemen otak untuk kepastian kesuksesan (Elex Media Komputindo, 2008), 2.

${ }^{10}$ Pasiak, Manajemen Kecerdasan. 


\section{The Way Your Brain Is Organised}

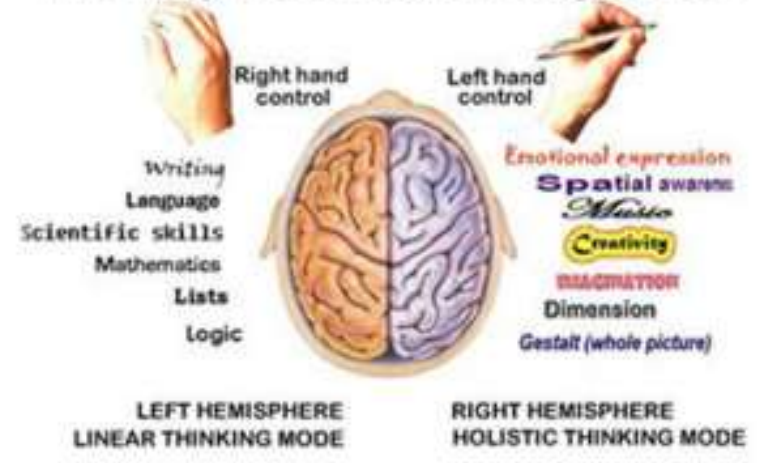

Gambar 1 :Cara berpikir otak kiri dan kanan

Ketika melakukan pembelajaran dengan cara-cara yang umum, sebenarnya saat itu yang digunakan hanya separuh bagian otak - yaitu otak belahan kiri. Betapa sia-sianya otak bagian kanan yang kurang dioptimalkan. Sesungguhnya otak bagian kanan sekalipun dapat dimanfaatkan untuk melakukan tugas-tugas pembelajaran. Tentu saja dengan cara-cara yang mendukung kedua belahan otak tersebut bekerja bersamaan.

Perubahan paradigma tentang organisme manusia yang utuh dikukuhkan dengan banyak penemuan neurosains yang menyibak kedahsyatan otak manusia. Otak manusia terbukti merupakan bagian tubuh yang tidak saja dicirikan oleh komponen-komponen struktural. Otak manusia merupakan bagian tubuh yang kedahsyatannya terjadi karena kesalingbergantungan seluruh komponen-komponennya. Kedahsyatan otak terjadi karena adanya sirkuit canggih yang terbentuk ketika semua komponen otak bekerja bersama secara harmonis. ${ }^{11}$

Semua potensi kecerdasan pada manusia akan teraktualisasi secara optimal apabila dilakukan intervensi-intervensi terhadap otak yang mengembangkan kecerdasan-kecerdasan tersebut. Untuk itu stimulasi yang diberikan dalam proses pembelajaran harus mengacu pada kerja otak tiap-tiap anak. Anatomi otak manusia dapat dilihat sebagai berikut:

\footnotetext{
${ }^{11}$ dr H. Taufiq Pasiak M.Kes M. Pd I., Brain Management for Self
} Improvement (Mizan Pustaka, 2007), 29. 


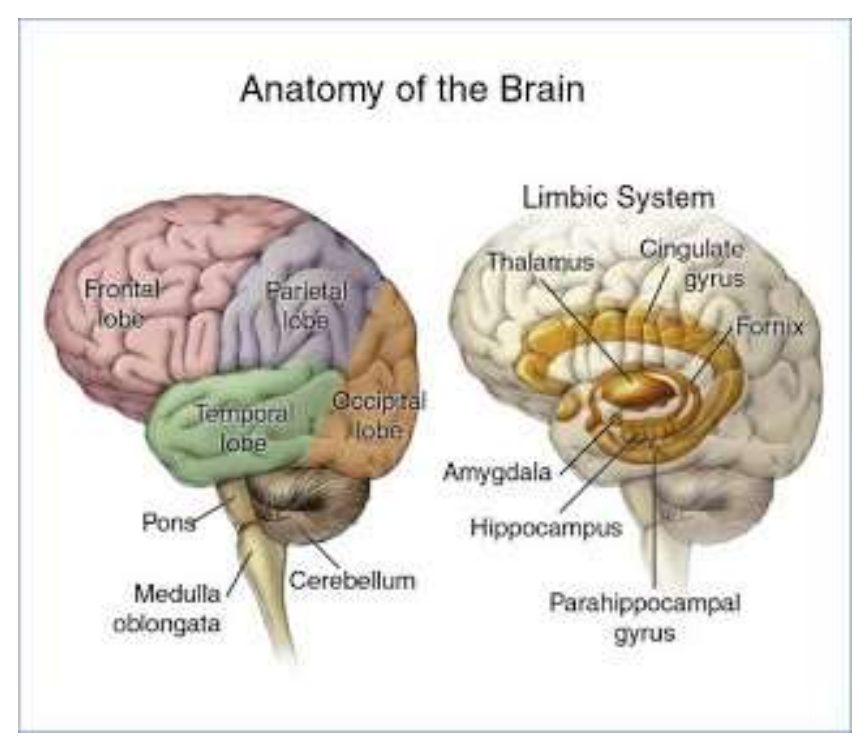

Gambar 2: Anatomi Otak

Sepuluh hukum dasar otak yang relevan menurut Taufik Pasiak dalam dunia pendidikan dapat dijabarkan sebagai berikut:

\section{Keunikan}

Sebagai system yang hidup otak berubah setiap hari. Sel-sel saraf merespon perubahan-perubahan itu melalui konsolidasi dan koneksi antar sel saraf. Yang paling hebat otak dapat berkembang secara tak terbatas (unlimited) tanpa memperbesar ukuran tengkorak kita. Otak juga tidak pernah beristirahat, sekalipun saat tidur otak tetap bekerja.

Otak harus senantiasa dirangsang agar potensi optimalnya muncul. Sebagaian besar ahli otak memperkirakan bahwa kita baru memakai $20-50 \%$ dari potensi otak. Potensi alam bawah sadar, intuisi dan konektivitas belum dipakai secara baik. $^{12}$

\section{Kekhususan}

Kekhususan ini sesuai teori Gardner seorang ahli Saraf dan pendidikan dari sekolah kedokteran Boston dan sekolah pendidikan Harvard yang menemukan 8 kemampuan berkaitan dengan kekhususan seseorang dalam memanfaatkannnya. Delapan kemampuan ini yang

\footnotetext{
${ }^{12}$ Pasiak, Manajemen Kecerdasan.
} 
kemudian sekarang berkembang menjadi Sembilan kemampuan dikenal dengan multiple intelligence.

Prinsip yang kedua ini menunjukkan adanya keunggulan yang bersifat khas pada setiap orang. Anak yang unggul dalam bidang mathematic-logic tidak berarti lebih pintar dari anak yang juara dalam setiap lomba lari. Dengan adanya prinsip ini semestinya dunia pendidikan memberikan ruang untuk setiap kecerdasan yang dimiliki setiap anak.

\section{Sinergitas}

Otak berkoordinasi dengan semua bagian tubuh yang lain termasuk oragn-orang gerak dan juga organ indera. Bagian motoric dan sensorik di otak memiliki hubungan saraf melalui pelepasan zat-zat kimi bernama neurotransmitter dengan indera dan organ gerak. Rangsangan yang diberikan pada beberapa organ akan memberikan efek yang lebih baik dibandingkan dengan hanya 1 organ. Otak akan lebih cepat menangkap informasi yang melibatkan dua kelompok organ ini sekaligus. Informasi juga akan lebih efektif tersampaikan jika dimasukkan pada gelombang tertentu.

Gelombang Otak manusia terdiri dari empat jenis. Yaitu beta, alpha, theta dan delta. Gelombang otak menentukan kesadaran seseorang pada waktu-waktu tertentu. Beta adalah gelombang otak pada saat sadar, alfa adalah gelombang otak pada saat santai, theta adalah gelombang yang dihasilkan oleh bawah sadar, dan delta adalah gelombang otak pada saat tidur. Kondisi hypnosis berada pada gelombang alfa dan theta. Ketika seseorang berada pada kondisi alfa dan theta, ia dapat belajar lebih cepat dari biasanya. ${ }^{13}$

\section{Hemisfirik dan Dominasi}

Dalam prinsip ini setiap orang memiliki gaya dan cara yang unik dalam belajar, pemerolehan informasi serta cara setiap orang dalam memecahkan masalah berbeda-beda. Namun sesungguhnya setiap orang dapat menjadi kreatif jika ia mengetahui bagaimana memanfaatkan otak rasional (otak

${ }^{13}$ Agus Sutiyono, Dahsyatnya Hypnoparenting (Depok: Penebar Plus), accessed March 4, 2016,

https://books.google.co.id/books?id=E71bHE3txzwC\&pg=PA73\&dq=h ypnoparenting\&hl $=$ en $\&$ sa $=X \&$ redir_esc $=\mathrm{y} \# \mathrm{v}=$ onepage $\& \mathrm{q}=$ hypnoparent ing $\& \mathrm{f}=$ false. 
kiri) dan otak kreatif (otak kanan)nya. Dari prinsip ini bisa dipahami jika setiap orang memiliki thinking style yang unik, begitu juga setiap anak didik memiliki keunikan dalam berpikir.

\section{Verba-Grafis}

Prinsip verba-Grafis ini menunjukkan bahwa otak akan lebih mudah menyerap informasi yang dikemas dalam bentuk kata-kata (verba) dan gambar (grafis). Prinsip ini mendasari teknik mencatat dengan mind mapping. Dengan teknik ini, catatan dibuat ditengah halaman lalu menyebar melalui garis-garis yang tampak seperti batang, cabang dan ranting sebuah pohon.

\section{Plastisitas Sel Saraf}

Tidak seperti sel-sel tubuh yang lain, sel-sel saraf tidak berganti-ganti pada kurun waktu tertentu. Jika rusak, sel saraf sangat sulit akan tumbuh lagi. Pada usia-usia tertentu, sel saraf akan menghilang dan mengurangi fungsi pada bagian yang hilang itu. Daya tahan hidup sel saraf berkaitan dengan prinsip use and disuse atau plastisitas. Semakin sering otak dipakai, semakin banyak perubahan molecular yang terjadi dan semakin kuatlah memori.

\section{Imajinasi dan Fakta}

Seringkali kita mendengar bahwa pikiran yang positif akan menghasilkan perilaku positif begitu juga sebaliknya pikiran yang negative akan melahirkan perilaku yang negative. Ajarlah anak didik untuk membentuk dunia yang ideal, sekalipun itu hanya dalam benak (imajinasi) mereka. Secara konkrit dalam pembelajaran dapat menggunakan drama (sandiwara) untuk memudahkan informasi. Membawa anak didik berimajinasi, banyak penemuan-penemuan ilmiah yang berawal dari imajinasi.

\section{Simultanitas}

Ketika otak dirangsang oleh sebuah informasi, maka seluruh bagian otak bekerja serempak. Jika seluruh bagian otak dapat dirangsang untuk bekerja secara serempak, penyerapan informasi akan menjadi lebih efektif. Cara kerja otak yang seperti ini dapat dipakai untuk merancang teknik belajar yang memadukan rekayasa detail seperti warna, bentuk dan aktivitas fisik. 


\section{Simbiosis}

Kulit otak, system limbik dan batang otak merupakan 3 sistem otak yang memiliki spesifikasi masing-masing, tetapi berkaitan erat ketika melakukan sebuah fungsi. Mc. Lean menggambarkan ketiga bagian tersebut dengan istilah "Tri in One". Batang Otak (inti hitam), limbic (lapisan merah) dan korteks (warna biru atau dikenal dengan topi berpikir). ${ }^{14}$ Gambarannya adalah sebagai berikut:

\section{Triune Brain}

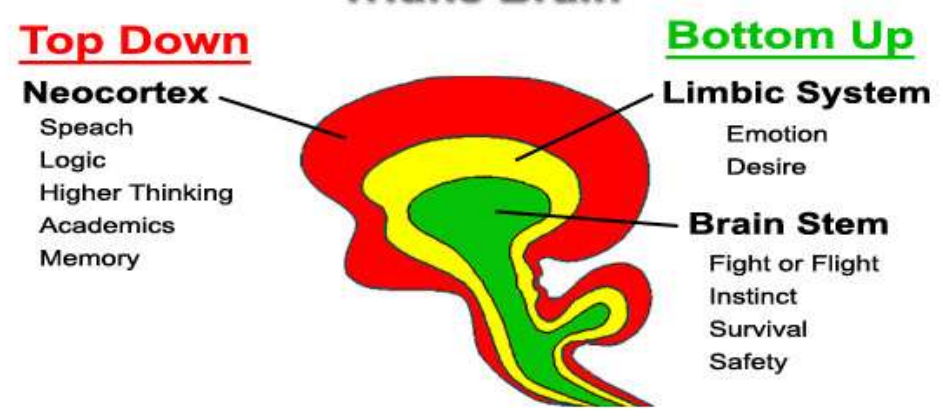

Gambar 3. Triune Brain

Kulit otak (korteks) berfungsi untuk berpikir rasional, kalkulatif dan intuitif, termasuk untuk pengaturan bahasa dan memori. System limbic mengatur bioritme tubuh (melalui pelepasan hormon-hormon), emosi dan memori emosional. Sedangkan batang otak mengatur fungsi-fungsi vegetasi, seperti napas, denyut jantung, aliran darah, serta kemampuan motorik. Ketiga system ini tidak pernah terpisah dan tidak mungkin dipisahkan dalam proses berpikir dan merasa. $^{15}$

\section{Otak Lelaki-Otak Perempuan}

Menurut Louann Brizendine seorang dokter neuropsikiater (ahli saraf jiwa) di University of California menyatakan bahwa otak pria (male brain) dan wanita (female brain) memiliki perangi yang berbeda. Hal ini bisa dilihat dari

${ }^{14}$ Mukhtar Latif et al., Orientasi Baru Pendidikan Anak Usia Dini Teori Dan Aplikasi (Jakarta: Kencana, 2014), 256.

${ }^{15}$ Pasiak, Manajemen Kecerdasan, 59. 
perilaku sehari-hari anak didik laki-laki dan perempuan di kelas. ${ }^{16}$

Taufik Pasiak menjelaskan bahwa karena pengaruh hormonal pada saat pembentukannya, otak laki-laki dan otak perempuan menjadi berbeda secara struktural. Perbedaan struktur ini berdampak pada perbedaan dalam mengolah masalah, termasuk ketrampilan motoric tertentu. Sebagai contoh, pusat pengaturan bahasa pada otak perempuan lebih tersebar (diffuse) daripada otak lelaki yang lebih terpusat (focus) di otak kiri. Konsekuensinya perempuan lebih piawai dalam mengolah kata (lisan atau tulisan). ${ }^{17}$

Sepuluh hukum dasar otak (prinsip) ini dapat dijadikan acuan oleh para pendidik ataupun lembaga pendidikan dalam proses penyelenggaraan pendidikan. Sehingga pelaksanaan pembelajaran tidak lagi mengabaikan system kerja otak. Pendidikan tidak dapat dipisahkan dari pengelolaan otak, oleh karenanya brain based learning sudah semestinya diterapkan dalam pembelajaran. Sehingga segala potensi dalam diri anak didik dapat dikembangkan secara optimal.

\section{Brain Based Learning dalam Pendidikan Anak Usia Dini}

Tiga bagian otak yang disebut "Tri in one", dimana ada batang otak (Inti hitam), limbik (lapisan merah) dan korteks (warna biru atau dikenal dengan topi berpikir. Ketiganya perlu dikenalkan kepada pendidik dan orang tua, agar mereka memahami cara kerja serta fungsi dari masing-masing bagian tersebut. Jika pengetahuan dan pemahaman fungsi bagian otak menjadi dasar dalam pembelajaran anak usia dini, harapannya perlakuan terhadap anak usia dini baik dalam hal mendidik maupun komunikasi memperhatikan fungsi kerja otak dan apa akibatnya dalam pertumbuhan dan perkembangan otak anak. ${ }^{18}$

Pertama, batang otak dikenal sebagai fight (melawan) dan flight, bereaksi terhadap ingatan, bagian ini tiba-tiba bereaksi apabila dalam keadaaan ketakutan, ditakut-takuti, dikritik atau

${ }^{16}$ H.D Iriyanto, Learning Metamorphosis Hebat Gurunya Dahsyat Muridnya (Jakarta: Erlangga, 2012), 25.

${ }^{17}$ Pasiak, Manajemen Kecerdasan, 61.

${ }^{18}$ Latif et al., Orientasi Baru Pendidikan Anak Usia Dini Teori Dan Aplikasi. 
diancam. Apabila pendidik atau orang tua merangsang bagian otak ini dengan baik, maka yang akan mendominasi kegiatan anak adalah hal-hal yang negative.

Jalan terbaik dalam pembelajaran anak usia dini agar mencapai tujuan adalah dengan meminilisasi perkembangan bagian ini, menghindari ancaman atau intimidasi terhadap anakanak dalam setiap proses kegiatan belajar mengajar. Memperbanyak kegiatan positif dan sering-sering memberikan kata-kata sanjungan atau penghargaan untuk setiap kerja keras anak. Pendidik dan orang tua juga dapat melakukan pelarangan dengan memberikan penjelasan sebab akibatnya, tidak dengan membohongi atau menakut-nakuti. ${ }^{19}$ Menakut-nakuti hanya akan menimbulkan traumik di diri anak.

Kedua, limbik dikenal dengan tempat kasih sayang, pusat emosi. Apabila dalam keadaan nyaman dan aman serta menyenangkan, system limbic ini akan bekerja sangat baik. Pembelajaran dapat dioptimalkan pada saat keadaan ini. Sehingga penciptakan lingkungan belajar menyenangkan, aman dan nyaman dapat mengoptimalkan pembelajaran anak. ${ }^{20}$

Ketiga, Korteks dikenal sebagai pusat berpikir atau kreativitas. Apabila system limbic mendapatkan perlakuan yang menyenangkan, maka selaput otak pada korteks akan bekerja dengan baik dan bertanggung jawab, atas berpikir nalar, analitis, perencanaan, pengorganisasian, bicara, penglihatan dan pendengaran. $^{21}$

Dalam pembelajaran berbasis otak (brain based learning) pendidik dan orang tua haruslah memiliki pengetahuan akan fungsi-fungsi bagian otak tersebut. sehingga dapat menciptkan pembelajaran yang efektif dan pada akhirnya tujuan pembelajaran akan tercapai.

Anak Usia Dini memiliki karakteristik belajar yang berbeda dengan orang dewasa. Belajar pada anak usia dini dilakukan dengan kegiatan bermain, karna dunia anak adalah

\footnotetext{
${ }^{19}$ IbiLatif et al., Orientasi Baru Pendidikan Anak Usia Dini Teori Dan Aplikasi

${ }^{20}$ IbLatif et al., Orientasi Baru Pendidikan Anak Usia Dini Teori Dan Aplikasi.

${ }^{21}$ IbLatif et al., Orientasi Baru Pendidikan Anak Usia Dini Teori Dan Aplikasi
} 
duni bermain. Dengan brain based learning guru dapat menerapkan metode-metode yang tepat, menciptakan lingkungan yang menyenangkan dan menciptakan suasana aman. Sehingga anak-anak dapat menikmati pembelajaran.

Pengenalan emosi yang sedang dialami peserta didik juga sangat bermanfaat bagi efektivitas pembelajaran. Karna suasa emosi yang maik (good mood), terutama lagi pada anak usia dini akan sangat berpengaruh terhadap proses pembelajaran. Pendidik pada anak usia dini harus mampu mengenali suasana hati peserta didik sebelum memulai pembelajaran. Sehingga proses pembelajaran akan lebih efektif dan hasilnya pun optimal.

Brain based learning adalah sebuah konsep untuk menciptakan pembelajaran dengan berorientasi pada upaya pemberdayaan potensi otak anak. Dengan tiga strategi utamanya yakni: pertama, menciptakan lingkungan belajar yang menantang kemampuan berpikir anak, kedua menciptakan lingkungan belajar yang menyenangkan, ketiga, menciptakan situasi belajar yang aktif (active learning) dan bermakna bagi anak didik. ${ }^{22}$

Diantara berbagai temuan para ahli tentang kemampuan otak dalam hal belajar, Barbara K Given dalam bukunya Brain Based Teaching menyebutkan bahwa otak manusia memiliki kemampuan belajar menurut lima versi. ${ }^{23}$

Pertama, versi emosional. Dalam versi ini otak mempelajari halhal yang terkait dengan hasrat (passion). Untuk itu pembelajaran harus didesain secara menarik dan memotivasi agar meninggalkan kesan pada anak didik. Di sini pendidik berperan sebagai mentor.

Kedua, versi sosial. Dalam versi ini otak pendidik dan anak didik akan mempelajari hal-hal yang berkaitan dengan interaksi sosial. Di sini pendidik berperan sebagai mitra.

\footnotetext{
${ }^{22}$ Jensen Eric, Brain Based Learning, Pembelajaran Berbasis Kemampuan Otak, Cara Baru Dalam Pengajaran Dan Pelatihan (Yogyakarta: Pustaka pelajar, 2008).

${ }^{23}$ IbJensen Eric, Brain Based Learning, Pembelajaran Berbasis Kemampuan Otak, Cara Baru Dalam Pengajaran Dan Pelatihan (Yogyakarta: Pustaka pelajar, 2008). hlm. 39.
} 
Ketiga, versi kognitif. Dalam versi ini otak pendidik dan anak didik mempelajari hal-hal yang berkaitan dengan rasio dan logika. Maka pembelajaran dalam hal ini harus memberikan inspirasi, posisi pendidik sebagai fasilitator.

Keempat, versi fisik. Dalam versi ini otak pendidik dan anak didik mempelajari aktivitas fisik. Untuk itu pembelajaran dengan versi ini harus enerjik dan dinamis, pendidik di sini berkedudukan sebagai pelatih.

Kelima,versi reflektif.Dalam versi ini otak pendidik dan anak didik mempelajari hal-hal yang berkaitan dengan eksistensi diri. Maka pembelajaran pada prinsip ini haruslah imajinatif dan siap-siap menjadi pencari bakat anak-anak didik.

Selain versi kemampuan belajar tadi, setiap anak juga memiliki modalitas belajar yang berbeda-beda. Ada yang menonjol di visual (belajar dengan melihat), ada yang menonjol di auditorinya (belajar dengan mendengar), dan ada pula yang menonjol kinestetiknya (belajar dengan bergerak). Karena itu menggunakan merode pembelajaran yang variatif tentunya akan melahirkan hasil belajar yang lebih baik.

Menurut Munif Chatib, konsultan multiple intelligence, meskipun anak memiliki modalitas belajar yang berbeda-beda, namun secara umum modalitas kinestetislah yang akan menghasilkan daya serap yang paling tinggi. ${ }^{24}$. Gambaran gaya belajar anak adalah sebagai berikut:

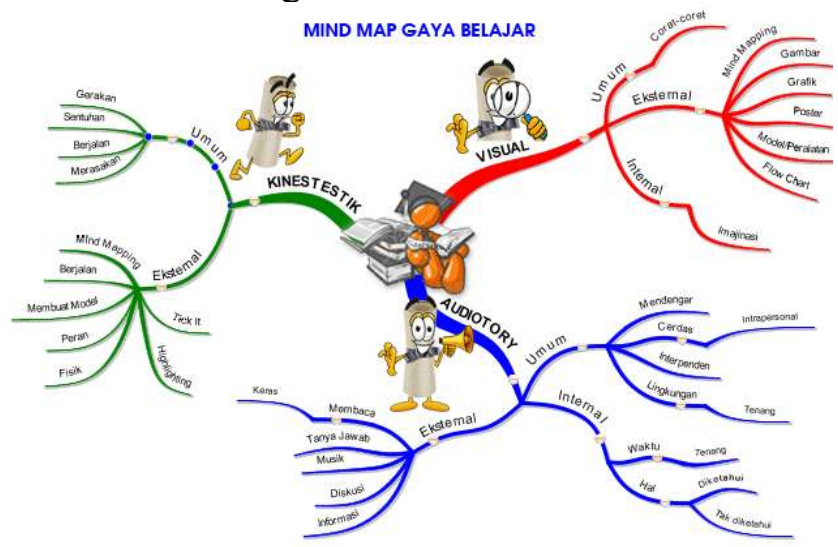

Gambar 4. Gaya Belajar

${ }^{24}$ IbJensen Eric, Brain Based Learning, Pembelajaran Berbasis Kemampuan Otak, .... hlm. 39 
Ketika pendidik telah memahami gaya belajar anak didik, maka harapannya model pembelajaran yang digunakan disesuaikan dengan kondisi anak didik tersebut. Pendidik bisa mengatur kondisi dimana nantinya informasi (pengetahuan) yang akan disampaikan dapat terserap dengan baik oleh anak didik. Sehingga dapat memberikan pengalaman atau pengetahuan baru bagi mereka.

Dengan mengetahui gaya belajar maka pemahaman yang didapat akan lebih optimal. sebuat teori VAK (Visual-AuditoriKinestetik) menyatakan bahwa seseorang bisa merupakan pembelajar yang kuat atau lemah dalam salah satu bidang ini. Jika termasuk cara pembelajar visual maka cara terbaik adalah dengan melihat informasinya. Namun jika termasuk dalam pembelajar auditori maka akan lebih baik jika mendengarnya, begitupun dengan pembelajar kinestetik, akan lebih tepat belajar dengan melibatkan gerakan fisik. ${ }^{25}$

Selain mengenali gaya belajar, yang perlu dipahami tentang potensi otak anak dalam pembelajaran anak usia dini adalah terkait dengan amygdala yang berkembang pesat pada usia 4 tahun. Dimana disebutkan bahwa amygdala terkait dengan memori yang mencatat rasa/emosi. Sehingga semestinya menjadi acuan bagi pendidik anak usia dini untuk merancang pembelajaran. Disesuaikan dengan perkembangan bagian otak tersebut, maka alangkah baik jika pembelajaran dirancang dengan hal-hal permainan yang melibatkan rasa, selain itu juga permainan melibatkan ketiga gaya belajar yang tadi telah disebutkan. Dengan demikian potensi otak anak usia dini akan berkembang optimal dan terpatri kuat hingga kelak dewasa.

Permainan-permainan yang dilakukan untuk mengembangkan potensi otak anak usia dini tentunya adalah permainan yang mangandung nilai-nilai edukatif. Dalam permainan bisa dirancang untuk pengembangan IQ, EQ dan SQ, sehingga dapat membentuk karakter anak.

Menurut Elizabeth B Hurlock, aktivitas bermain memiliki pengaruh yang besar terhadap: 1) perkembangan fisik, 2) dorongan berkomunikasi, 3) penyaluran energi emosional terpendam, 4) Penyaluran bagi kebutuhan dan keinginan, 5)

\footnotetext{
${ }^{25}$ bobbi DePorter, Quantum Success (Bandung: Mizan Pustaka, 2006),
} 194. 
sumber belajar, 6) rangsangan bagi kreatifitas, 7) perkembangan konsep diri, 8) belajar bermasyarakat/ bersosialisasi, 9) standar moral, 10) standar moral 11) belajar bermain sesuai dengan peran jenis kelamin 12) perkembangan ciri kepribadian yang diinginkan. ${ }^{26}$

Bermain adalah salah satu cara memposisikan potensi otak anak dalam pembelajaran. Bermain juga merangsang perkembangan otak anak, karena dari bermain anak-anak mendapatkan informasi baru yang akan diolah otak menjadi pengetahuan. Bermain menjadi cara yang cocok dalam pembelajaran anak usia dini.

Anak usia dini belajar melalui serangkaian kegiatan permaian yang menyenangkan yang didesain baik oleh pendidik maupun orang tua. Untuk menciptakan suatu pembelajaran yang menyenangkan sekaligus mengoptimalkan potensi otak anak, pendidik haruslah menggunakan model pembelajaran yang sesuai. Misalnya saja pendidik dapat menggunakan quantum learning untuk pembelajaran anak usia dini padukan dengan strategi-strategi pembelajaran aktif (active learning). Dengan demikian diharapkan hasil yang diperoleh dari proses pembelajaran akan lebih optimal.

\section{Quantum Learning}

Sejak buku Quantum Learning diterbitkan di Indonesia, perhatian para pegiat pendidikan terhadap otak kiri dan otak kanan menjadi semakin besar. Di buku itu, Bobbi DePorter dan Mike Hernacki, menjelaskan bahwa eksperimen terhadap dua belahan otak (kiri dan kanan) menunjukkan bahwa masingmasing belahan otak bertanggung jawab terhadap cara berpikir seseorang. ${ }^{27}$ Selain itu, masing-masing belahan (hemisfer) mempunyai spesialisasi dalam kemampuan tertentu, yang oleh Taufiq Pasiak disebut sebagai dominasi. Walaupun ada beberapa persilangan dan interaksi di antara keduanya.

Quantum Learning bermula dari upaya Dr. Georgi Lozanov, seorang pendidik berkebangsaan Bulgaria yang yang $39-41$.

${ }^{26}$ Andang Ismail, Education Games (Yogyakarta: Pro U Media, 2009),

${ }^{27}$ Iriyanto, Learning Metamorphosis Hebat Gurunya Dahsyat Muridnya, 28. 
bereksperimen dengan apa yang disebutnya sebagai suggestology atau suggestopedia. Prinsipnya adalah bahwa sugesti dapat dan pasti mempengaruhi hasil situasi belajar, dan situasi apapun pasti memberikan sugesti positif atau negative. Beberapa teknik yang digunakannya untuk memberikan sugesti positif adalah dengan mendudukkan murid dengan nyaman, memutar musik di ruang kelas, meningkatkan partisipasi individu, menggunakan poster-poster untuk memberikan kesan besar sambil menonjolkan informasi, dan menyediakan guruguru yang terlatih baik dalam seni pengajaran sugestif. ${ }^{28}$

Pembelajaran utamanya pada anak usia menuntut adanya pembelajaran yang holistik (menyeluruh), dengan mempertimbangkan teori otak kanan dan kiri serta prinsip kerja 3 in 1 (tri in one) dalam otak serta kecerdasan majemuk (multiple Intelligences). Dengan quantum learning semua prinsip tersebut dalam di akomodir. Pembelajaran quantum ini menggabungkan sugestology dengan pemercepatan belajar (accelerated learning) serta Neuro Linguistic Programme (NLP) yang dikemas dalam permainan serta penciptaan lingkungan yang menyenangkan.

Neuro Linguistik Programme (NLP) berkaitan dengan hubungan antara bahasa dengan perilaku. Pendidik perlu memiliki pengetahuan tentang hal ini. Bagaimana seorang pendidik meningkatkan penggunaan bahasa yang positif untuk mendapatkan hasil perilaku yang positif. Tidak sedikit guru yang belum bisa memilih bahasa yang positif sehingga justru menekan anak didik. Dan akhirnya hasil yang positif pun sulit untuk didapatkan.

Dr. Paul MacLean, Dr Joseph LeDoux dan Dr Daniel Goleman menyatakan bahwa ketika otak menerima ancaman atau tekanan, kapasitas saraf untuk berpikir rasional mengecil. Otak "dibajak secara emosional". Akibatnya otak tidak dapat

\footnotetext{
${ }^{28}$ bobbi DePorter and Mike Hernacki, Quantum Learning - Bobbi De Porter \& Mike Hernacki - Google Books (Bandung: Mizan Pustaka, 2007), 14 , https://books.google.co.id/books?id=6_Nx2_6T2cAC\&printsec=frontcover\& $\mathrm{dq}=$ quantum+learning + Bobbi + DePorter $\& \mathrm{hl}=$ en $\& \mathrm{sa}=\mathrm{X} \& \mathrm{ved}=0$ ahUKEwin 97 L3sqfLAhXE1I4KHd5mBe4Q6AEIIDAB\#v=onepage \&q=quantum\%20learn ing\%20Bobbi\%20DePorter\&f=false.
} 
mengakses Higher Order Thinking Skill (HOTS) - Ketrampilan Berpikir Tingkat Tinggi. Fenomena ini dikenal dengan Downshifting, merupakan tanggapan psikologis yang menghentikan proses belajar. Sebaliknya dengan tekanan positif atau supportif, yang dikenal dengan eustress, otak dapat terlibat secara emosional dan memungkinkan kegiatan saraf maksimal. ${ }^{29}$

Penerapan quantum learning oleh guru melalui quantum teaching menggunakan filosifi TANDUR yang maknanya: ${ }^{30}$

T : Tumbuhkan (menumbukan minat dengan memuaskan "Apakah Manfaatnya BAgiKu (AMBAK) dan manfaatkan kehidupan pelajar

A : Alami (ciptakan atau datangkan pengalaman umum yang dapat dimengerti semua pelajar)

N : Namai (Sediakan kata kunci, konsep, model, rumus, strategi)

D : Demonstrasikan (sediakan kesempatan kepada pelajar untuk menunjukkan bahwa mereka tahu)

U : Ulangi (tunjukkan pelajar cara-cara mengulang materi dan menegaskan "Aku tahu bahwa aku memang tahu ini")

R : Rayakan (pengakuan untuk penyelesaian, partisipasi dan pemerolehan ketrampilan dan ilmu pengetahuan)

Dalam mengaplikasikan quantum learning, ada teknik yang sering dilakukan yang biasa disebut dengan AMBAK (Apa Manfaatnya BAgiKu). Teknik seperti ini dilakukan guna menumbuhkan minat atau motivasi diri terhadap apa yang akan dipelajari. Adanya minat atau motivasi ini akan berdampak pada keberhasilan belajar. Di dalam pendidikan anak usia dini menumbuhkan minat sudah tidak asing lagi, karena pembelajaran biasannya dilakukan sesuai minat anak didik. Dan keberhasilan belajar sering kali dirayakan dengan tepukan tangan.

Dalam quantum teaching tidak kalah pentingnya adalah mendesain konteks yakni menciptakan suasana yang memberdayakan, landasan yang kukuh, lingkungan yang mendukung serta rancangan belajar yang dinamin. Selanjutnya dalam sesi isi, seorang pendidik harus memperhatikan penyajian

${ }^{29}$ bobbi DePorter, Quantum Teaching Mempraktikkan Quantum Learning Di Ruang-Ruang Kelas (Bandung: Mizan Pustaka, 2001), 22.

${ }^{30}$ Ibid., 10. 
yang prima, fasilitas yang luwes, ketrampilan belajar untuk belajar serta ketrampilan hidup.

Prinsip yang tidak boleh ditinggalkan dalam pembelajaran quantum adalah "bawalah dunia mereka ke dunia kita, dan antarkan duni kita ke dunia mereka". Kaidah ini memberikan petunjuk bagi pendidik, bahwasanya sebelum melakukan proses pembelajaran. Pendidik harus lebih dulu diterima oleh anak didik. Menurut DePorter, surat keputusan mengajar sebagai guru memberikan seorang pendidikan otoritas mengajar, namun bukan hak mengajar. Karena hak mengajar harus diraih karena anak didik akan memberikannya dengan sukarela apabila anda sudah dapat memasuki dunia mereka begitu juga sebaliknya. ${ }^{31}$

Model pembelajaran konvensional selama ini yang sudah berlangsung selama bertahun-tahun lamanya, adalah model pembelajaran otak kiri. Sehingga cenderung mengabaikan otak kanan. Padahal untuk tujuan pendidikan yang sesungguhnya maka pendidik diharapkan dapat mencetak tidak hanya anak didik yang pintar namun anak didik yang trampil sehingga mereka mampu mengisi kehidupannya dalam rangka memperoleh kebahagian dunia dan akhirat. Melalui pembelajaran quantum yang memperhatikan prinsip-prinsip otak kanan dan kiri diharapkan pendidik-pendidik masa kini dapat mencetak generasi yang cerdas dan trampil.

\section{Simpulan}

Berdasarkan pemaparan diatas dapat disimpulkan bahwa ada 10 hukum dasar otak yang dapat digunakan dalam pembelajaran yaitu: 1) keunikan, 2) kekhususan, 3) sinergisitas, 4) hemisferik dan dominasi, 5) verba-grafis, 6) plastisitas sel saraf, 7) imajinasi dan fakta, 8) simultanitas, 9) simbiosis, 10) otak laki-laki dan otak perempuan. Kesemua hukum dasar tersebut sangat berpengaruh dalam pembelajaran anak usia dini.

Salah satu pembelajaran berbasis kerja otak (brain based learning) adalah dengan menggunakan pembelajaran quantum. Dalam pembelajaran quantum yang harus diperhatikan adalah pendidik harus bisa membawa dunia anak didik kepada dunianya dan mengantarkan dunianya kepada dunia anak didik.

\footnotetext{
${ }^{31}$ Iriyanto, Learning Metamorphosis Hebat Gurunya Dahsyat Muridnya,
} 74. 
Pembelajaran quantum dilandasi filosofi TANDUR, yang didahului dengan Tumbuhkan, yakni menumbuhkan minat atau motivasi diri, melalui AMBAK (Apa Manfaatnya BAgiKu).

Pembelajaran quantum memberikan ruang untuk berkembangnya potensi otak dalam pembelajaran. Setiap invidu memiliki potensi yang berbeda, keunikan tersebut juga berdampak pada learning style yang berbeda pula. Ada gaya belajar visual, auditory dan kinestetik. Untuk mengoptimalkan potensi otak semestinya pendidik, pengelola dan orang tua anak usia dini harus mengenali betul potensi yang serta gaya belajar yang ada pada masing-masing anak.

\section{Daftar Pustaka}

DePorter, bobbi. Quantum Success. Bandung: Mizan Pustaka, 2006.

. Quantum Teaching Mempraktikkan Quantum Learning Di Ruang-Ruang Kelas. Bandung: Mizan Pustaka, 2001.

DePorter, bobbi, and Mike Hernacki. Quantum Learning Bandung: Mizan Pustaka, 2007.

Direktorat Pendidikan Anak Usia Dini. Pedoman Penerapan Pendekatan "Beyond Centers And Circle Time (BCCT)", (Pendekatan Sentra Dan Lingkaran) Dalam Pendidikan Anak Usia Dini. Jakarta: Departemen Pendidikan Nasional, 2006.

El Khuluqo, Ihsana. Manajemen PAUD (Pendidikan Anak Usia Dini) Pendidikan Taman Kehidupan ANak. Yogyakarta: Pustaka pelajar, 2015.

Iriyanto, H.D. Learning Metamorphosis Hebat Gurunya Dahsyat Muridnya. Jakarta: Erlangga, 2012.

Ismail, Andang. Education Games. Yogyakarta: Pro U Media, 2009.

Jensen Eric. Brain Based Learning, Pembelajaran Berbasis Kemampuan Otak, Cara Baru Dalam Pengajaran Dan Pelatihan. Yogyakarta: Pustaka pelajar, 2008.

Latif, Mukhtar, Zukhairini, Rita Zubaidah, and Muhammad Afandi.

Orientasi Baru Pendidikan Anak Usia Dini Teori Dan Aplikasi. Jakarta: Kencana, 2014.

Pasiak, Taufiq, Brain Management for Self Improvement. Mizan Pustaka, 2007.

Nur Chamidah, Atiek. "Pentingnya Stimulasi Dini Bagi Tumbuh Kembang Otak Anak," n.d. 
Pasiak, Taufiq. Manajemen Kecerdasan. Bandung: Mizan Pustaka, 2007.

Rochmad Ali, Noor, Jazariyah, and Rina Roudlatul Jannah.

Perkembangan Dan Permainan Edukatif Anak Usia Dini. Yogyakarta: Editie Pustaka, 2016.

Santrock, J.W. Life-Span Development Perkembangan Masa Hidup. Edisi Kelima. Jakarta: Erlangga, 2002.

Sutiyono, Agus. Dahsyatnya Hypnoparenting. Depok: Penebar Plus. 2016.

Suyanto, S. Konsep Dasar Pendidikan Anak Usia Dini. Jakarta:

Departemen Pendidikan Nasional, 2005.

Windura, Sutanto. Definite success with brain management: panduan manajemen otak untuk kepastian kesuksesan. Elex Media Komputindo, 2008. 